\title{
Decolonization of STEM in the Public Education System in Québec, Canada
}

\section{$\underline{\text { Emma C. Anderson }}^{1,2^{*}}$, Kaitlyn Easson ${ }^{1,3^{*}}$, $\underline{\text { Saina Beitari }}^{1^{*}}$, $\underline{\text { Maïa Dakessian }}^{1,4^{*}}, \underline{\text { Sai Priya Anand }}^{1,5^{*}}, \underline{\text { Sumedha Sachar }}^{1 *}$, Jessica Bou Nassar ${ }^{1,2^{*}}$}

${ }^{1}$ Science \& Policy Exchange Canada

${ }^{2}$ McGill University, Department of Bioresource Engineering, Ste-Anne-de-Bellevue, Québec, Canada

${ }^{3}$ McGill University, Integrated Program in Neuroscience, Montreal, Québec, Canada

${ }^{4}$ University of Montreal, Department of Social and Preventive Medicine, School of Public Health (ESPUM),

Montreal, Québec, Canada

5McGill University, Department of Microbiology and Immunology, Montreal, Québec, Canada

*All authors contributed equally

DOI hyperlink: https://doi.org/10.38126/JSPG180402

Corresponding author: emma.anderson2@mail.mcgill.ca

Keywords: STEM; Indigenous ways of knowing; public education; decolonization; reconciliation; STEM education in Canada

Executive Summary: Indigenous representation in science, technology, engineering, and mathematics (STEM) is crucial for reconciliation, self-determination, and inclusive and equitable science policy. Indigenous people continue to be underrepresented in Canada's STEM workforce, creating a substantial annual cost to the Canadian economy. Canada's provinces and territories hold jurisdiction over education, and the majority, including Québec, do not include Indigenous perspectives in their elementary and secondary STEM curricula. This exclusion can alienate Indigenous learners and deter them from STEM careers. As a model for the decolonization of STEM in other provinces, we call for the amendment of Québec's Education Act to create an Indigenous Education Steering Committee (IESC), which would collaborate with the Minister of Education to ensure inclusion of locally relevant Indigenous STEM content in compulsory curricula. We further propose that Québec include continued professional development training for teachers on Indigenous perspectives in STEM in the Ministry of Education's strategic plan, thereby building capacity for the equitable participation of Indigenous peoples in STEM.

\section{Introduction}

The demand for skilled professionals in science, technology, engineering, and mathematics (STEM) in Canada is increasing, with a growth rate of approximately $4.5 \%$ per year, in comparison to the labor market's $1.8 \%$ annual growth (Cooper 2021; Patterson 2019). However, Indigenous peoples (First Nations, Métis, and Inuit) are underrepresented in these positions, accounting for $4 \%$ of the Canadian population but only $2 \%$ of STEM jobs (Statistics Canada 2016). Inclusion and representation of Indigenous people in STEM fields are critical to foster reconciliation through decolonization of education, to maximize economic opportunities for Indigenous people, to support self-determination by equipping them to work in STEM within their communities, and to facilitate the development of inclusive and equitable science policy (Cooper 2020). Enhanced Indigenous representation in STEM fields will also benefit the Canadian economy; the opportunity gap between Indigenous and non-Indigenous people costs the Canadian economy $\$ 27.7$ billion annually (National Indigenous Economic Development Board 2019). It is also important for the inclusive advancement of knowledge and prosperity through Two-Eyed Seeing, which builds on the 
complementary strengths of Indigenous ways of knowing and Western science (Hatcher et al. 2009). Unfortunately, conventional elementary and secondary STEM education in Canada is a barrier to increased Indigenous participation (American Indian Science and Engineering Society 2019).

STEM subjects are typically taught from a Eurocentric perspective that differs from Indigenous ways of knowing, alienating young Indigenous learners and devaluing the contribution of Indigenous beliefs, experiences, and knowledge to the classroom (Bang and Medin 2010). This in turn can discourage Indigenous students from pursuing post-secondary STEM education and subsequent careers (American Indian Science and Engineering Society 2019). Incorporating Indigenous perspectives with Western science in elementary and secondary curricula can increase the engagement and retention of Indigenous students in STEM subjects (Kanu 2007) and improve their performance on STEM standardized testing (Dupuis and Abrams 2017). Not only does greater Indigenous STEM participation facilitate greater economic opportunities and self-determination, but a diversity of perspectives and experiences in the STEM workforce benefits problem-solving, critical thinking, and global competitiveness (Ferrini-Mundy 2013). However, most provinces and territories have not integrated Indigenous perspectives into STEM education despite clear nationwide calls by The Royal Commission on Aboriginal Peoples (1996) and the Truth and Reconciliation Commission (2015) of Canada. This memo provides policy recommendations for the decolonization of STEM education in the province of Québec, where Indigenous perspectives are completely absent from STEM education. The province-specific policy recommendations provided herein can subsequently be used as a model to be adapted to other provinces and territories.

\section{Current state}

Cross-Canada differences in education policy are due to its governance structure; Canada divides powers between the federal government and ten regional provincial and three territorial governments, granting the provinces and territories exclusive jurisdiction over education (Constitution Act 1867). There is no nationwide education system, federal department of education, national curriculum standard, or federal law mandating Indigenous perspectives in STEM education. Instead, provincial and territorial ministries or departments of Education define the educational services, frameworks, funding, policies, and curricula and delegate administrative and operational duties to local school boards, districts, or service centers (Council of Ministers of Education, Canada n.d.).

The exception to provincial jurisdiction over education exists for First Nations reserve schools, which are the First Nations Bands and federal government's responsibility. However, only $20 \%$ of Indigenous people live on reserves (Statistics Canada 2016), with $40 \%$ of students attending provincial schools (Bains 2016). Therefore, most Indigenous students live and study off-reserve (CrownIndigenous Relations and Northern Affairs Canada 2011). In addition, $84 \%$ of on-reserve schools in Québec use the provincial curriculum (Commission de l'éducation en langue anglaise 2017).

Across Canada, while STEM is generally taught from a Western perspective, some provinces have made efforts to incorporate Indigenous perspectives, with Saskatchewan and British Columbia leading the way. In each province, consultations with Indigenous leaders and communities determined the best individualized approach. In Saskatchewan, Indigenous perspectives are fully incorporated into the core provincial science curriculum, as well as in the recommended provincial teaching materials, guided by collaboration with the Indigenous communities living in the province (Aikenhead \& Elliot 2010). Saskatchewan's provincial curriculum frames learning of both Eurocentric and Indigenous knowledge related to life, physical, and Earth or space sciences in the context of scientific inquiry, technological problem solving, cultural perspectives, and science, and decision making. In British Columbia, the new 2018 curriculum supports the incorporation of Indigenous perspectives in the core science curriculum (Cooper 2020). However, as British Columbia is the Canadian province with the greatest Indigenous diversity, the production of specific province-wide teaching materials is not appropriate. Instead, teachers are provided with tools and support to integrate local Indigenous perspectives by the province's First Nations Education Steering Committee (FNESC). In contrast, Québec does not incorporate Indigenous STEM perspectives in any aspect (Cooper 2020), despite 
being home to $10 \%$ of the Indigenous population living in Canada (Statistics Canada 2016) and eleven different Indigenous nations (Secrétariat aux affaires autochtones 2021).

Outside of government-mandated curricula, many Canadian non-profits provide resources for teachers to support the integration of Indigenous perspectives into science education and opportunities for students through workshops, camps, and special events.

\section{Policy options}

\section{i. Option 1: Prioritize allocation of funds to non-profit organizations}

Canadian non-profit organizations often receive funding from the federal and provincial governments. For example, the Natural Science and Engineering Research Council of Canada (NSERC) funds Indigenous youth in STEM (InStem), which holds school workshops and other educational resources to deliver Indigenous STEM content to increase high school graduation rates and interest in STEM careers (NSERC 2019). Moreover, the Canadian Institutes of Health Research (CIHR) funds the Québec Indigenous Mentorship Network Program (IMNP) to provide culturally relevant learning opportunities for Indigenous youth (CIHR 2019). The Québec Aboriginal Science and Engineering Association (QASEA) achieves this mission by organizing science fair programs, including workshops targeting Indigenous communities.

Increasing provincial funding opportunities for nonprofit organizations such as InSTEM and QASEA will allow them to impact more communities. We call on the Québec government to dedicate funding in its education budget for Indigenous-led non-profit organizations to deliver Indigenous STEM educational resources specific to Québec's Indigenous communities. Specifically, we recommend that Québec match the amount currently spent on promoting the educational success of Indigenous students (Gouvernement du Québec 2021 ) and provide an additional $\$ 8$ million annually to non-profit organizations for the provision of Indigenous STEM educational resources.

\section{Advantages}

Increasing funding for non-profit organizations would play an important role in bridging gaps and building community partnerships between provincial education systems and Indigenous communities. This funding would allow the organizations to expand their services and STEM programs to provide outreach services to more youth.

\section{Disadvantages}

Relying solely on non-profit organizations is not sustainable in the long term as the dedicated funds can change with future governments and the success of initiatives depends on the continued participation of volunteers. Furthermore, these programs might only be implemented in some communities, not reaching most Indigenous learners. Also, the resources are not guaranteed and are implemented on a case-by-case basis. Hence, there should be a sustainable systematic national or province-wide initiative to support incorporating Indigenous perspectives into STEM curriculum continuously.

\section{ii. Option 2: Establish an Indigenous Education} Steering Committee (IESC) in Québec

Curricula taught in Québec's public education system is governed by the Programme de formation de l'école québécoise (PFEC) or 'Québec Education Program (QEP)' (Ministère de l'éducation 2021). The PFEC outlines the compulsory curriculum for preschool, elementary, and secondary schools in Québec. The Comité d'agrément des programmes de formation à l'enseignement (CAPFE), or the 'Teacher Training Program Approval Committee', accredits Québec's teaching diploma programs by ensuring programs equip teachers to teach the PFEC curricula (Ministère de l'éducation 2021). The Minister of Education is granted the power to establish compulsory and elective subject matter through Section 461 of Division II of the Education Act (Légis Québec 2020). Therefore, the Minister is responsible for the contents and reform of the PFEC.

As such, we recommend that Québec's Ministry of Education creates an Indigenous Education Steering Committee (IESC) to oversee elementary and secondary STEM curriculum reform to integrate Indigenous perspectives into the PFEC. This committee would be composed of an Indigenous board of directors that represent and work on behalf of the Indigenous people and nations in Québec. The IESC will define what perspectives to add to the PFEC and further curriculum reform. We also propose that Section 461 of the Education Act be amended to 
include the IESC, wherein the Minister of Education must collaborate with the IESC to ensure the appropriate immersion of Indigenous content and perspectives in Québec's core and elective STEM curricula.

\section{Advantages}

The creation of an IESC will facilitate the reform of the PFEC to include Indigenous perspectives in STEM curricula through collaboration between Québec's Minister of Education and Indigenous peoples and communities. Additionally, amendment of Section 461 of the Education Act would legislatively protect the authority of the IESC to advise the Minister. Consequently, given that the CAPFE ensures that newly trained teachers can teach the PFEC, universities in Québec will be obliged to include subsequent reforms in their teaching diploma programs.

\section{Disadvantages}

Since CAPFE only accredits teaching diploma programs, not ongoing teaching licenses, it only ensures that newly trained teachers are taught curriculum reforms. Thus, this option would not ensure practicing teachers are trained to incorporate Indigenous perspectives appropriately and effectively.

\section{iii. Option 3: Add the incorporation of Indigenous} perspectives in STEM to Québec's Ministry of Education's Strategic Plan

There are sixty French-language school service centers in Québec's public education system that provide operational and administrative functions to schools in their districts, including continued professional development training for teachers (Ministère de l'éducation 2021). Under section 209.1 of the Education Act, school service centers must set their strategic direction and objectives regarding their functions in their Commitment-to-Success Plan (Légis Québec 2020). However, as per sections 459.2 and 459.3 of the Education Act, the Minister of Education can impose specific policy directions, objectives, or targets that must be included in each service center's Commitment-to-Success plan, as defined in the Ministry's five-year strategic plan (Légis Québec 2020).

We recommend that the Ministry's next and future five-year strategic plans include 1) an objective of increasing students' knowledge of Indigenous perspectives in STEM and 2) an associated axis of intervention of providing continued professional development training to teachers regarding Indigenous STEM content. Both 1) and 2) would be designed in consultation with Indigenous communities. Success metrics would also be identified jointly with Indigenous communities.

\section{Advantages}

Training programs that incorporate Indigenous perspectives in STEM can encourage in-service teachers to discuss Indigenous perspectives in the classroom.

\section{Disadvantages}

Although this option encourages teachers to teach Indigenous perspectives, it might not be as effective without concrete inclusion of Indigenous perspectives in STEM curricula through PFEC reform. Moreover, this policy only targets Service School Centers, excluding the nine English-language school boards that are part of Québec's public education system. Additionally, since the policy is only covered by the Ministry of Education's five-year strategic plan, continued professional development training to equip in-service teachers to incorporate Indigenous perspectives in STEM would need to be included in all future strategic plans.

\section{iv. Consequences of inaction}

A systematic failure to include and support Indigenous youth in Québec in STEM education and career pathways will persist without broad reform of Québec's education system to address the lack of Indigenous content and perspectives in elementary and secondary STEM education. Inaction will further exacerbate the underrepresentation of Indigenous people in rapidly growing STEM fields, preventing opportunities for economic prosperity, reconciliation, self-determination, and inclusive science and science policy.

\section{Recommendations}

We recommend implementing both Option 2 and Option 3 to mandate the inclusion of Indigenous knowledge into STEM curricula while also ensuring adequate training of both new and practicing teachers. Option 2 will have a more enduring impact by integrating Indigenous perspectives into Québec's elementary and secondary STEM curricula through 
PFEC reform. However, the inclusion of Option 3 as a transitional policy is vital to ensure that currently practicing teachers, whose primary training will not be altered by Option 2, are adequately trained to teach new Indigenous STEM curricula. Providing more funding for non-for-profit organizations is

\section{References}

Aikenhead, Glen S., and Dean Elliott. 2010. "An Emerging Decolonizing Science Education in Canada." Canadian Journal of Science, Mathematics and Technology Education 10, no. 4: 321-38. https://doi.org/10.1080/14926156.2010.524967.

American Indian Science and Engineering Society. 2019. "Literature review: STEM education for Native American students." Accessed March 3, 2021. https://www.aises.org/resource-center/publications

Bains, Ravina. 2014. "Myths and Realities of First Nations Education." Fraser Institute: Center for Aboriginal Policy Studies. Accessed April 29, 2021.

https://www.fraserinstitute.org/studies/myths-andrealities-first-nations-education.

Bang, Megan, and Douglas Medin. 2010. "Cultural Processes in Science Education: Supporting the Navigation of Multiple Epistemologies." Science Education 94, no. 6: 1008-026. https://doi.org/10.1002/sce.20392.

Canadian Institute of Health Research (CIHR). 2019. "CIHR Institute of Indigenous Peoples' Health." Accessed April 29, 2021.

https://cihr-irsc.gc.ca/e/49453.html

Commission De Léducation En Langue Anglaise, Québec. 2017. "Indigenous Education: Walking on Both Sides of the River: Brief Presented to the Minister of Education, Recreation and Sports." Montreal, Québec. https://numerique.banq.qc.ca/patrimoine/details/52 327/3280182.

Constitution Act. 1867. (UK), 30 \& 31 Vict, c 3. Accessed April 29, 2021.

https://www.canlii.org/en/ca/laws/stat/30---31-victc-3/latest/30---31-vict-c-3.html

Cooper, Jane. 2020. "Curriculum and Reconciliation: Introducing Indigenous Perspectives into K-12 Science." Ottawa: The Conference Board of Canada. Accessed April 7, 2021.

https://www.conferenceboard.ca/temp/d08078247bac-4fdd-a27b-d981dc302329/10772 impactpaper curriculum-and-reconciliation 1.pdf.

Cooper, Jane. 2021."STEM Education Must Be Reformed to Engage Indigenous Youth.” iPolitics, January 18, 2021. https://ipolitics.ca/2021/01/18/stem-educationmust-be-reformed-to-engage-indigenousyouth/?utm source=OP ED\&utm medium=SOCIAL\&ut $\underline{\text { m campaign }=\text { COMMS. }}$. critical (Option 1); however, it is not a sustainable long-term plan to widely incorporate Indigenous knowledge into STEM curricula. Upon establishment, these policies and frameworks can be a model for the inclusion of Indigenous STEM perspectives in education in other Canadian provinces and territories.

Council of Ministers of Education, Canada. n.d. "Education in Canada an Overview." Accessed March 12, 2021. https://www.cmec.ca/299/education-in-canada-anoverview/index.html.

Crown-Indigenous Relations and Northern Affairs Canada. 2011."The Report of the National Panel on First Nation Elementary and Secondary Education for Students on Reserve." Accessed March 15, 2021.

https://www.rcaanccirnac.gc.ca/eng/1373075023560/1609269832047

Dupuis, Juliann, and Eleanor Abrams. 2016. "Student Science Achievement and the Integration of Indigenous Knowledge on Standardized Tests." Cultural Studies of Science Education 12, no. 3: 581-604.

https://doi.org/10.1007/s11422-016-9728-6.

Ferrini-Mundy, Joan. 2013. "Driven by Diversity." Science 360, no. 6130: 278-78.

https://doi.org/10.1126/science.1235521.

Hatcher, Annamarie, Cheryl Bartlett, Albert Marshall, and Murdena Marshall. 2009. "Two-Eyed Seeing in the Classroom Environment: Concepts, Approaches, and Challenges." Canadian Journal of Science, Mathematics and Technology Education 9, no. 3: 141-53. https://doi.org/10.1080/14926150903118342.

Gouvernment du Quebec. 2021. "Un Québec Résilient et Confiant: Plan Budgétaire." Accessed June 1, 2021. http://www.budget.finances.gouv.qc.ca/budget/20212022/

Kanu, Yatta. 2007. "Increasing school success among Aboriginal students: Culturally responsive curriculum or macrostructural variables affecting schooling?" Diaspora, Indigenous, and Minority Education 1, no. 1: 21-41. https://doi.org/10.1080/14926150903118342.

Légis Québec. 2020. "Education Act.” Accessed April 29, 2021.

http://legisquebec.gouv.qc.ca/en/showdoc/cs/i-13.3.

Ministère de l'éducation, Québec. 2021 "Comité d'agrément des programmes de formation à l'enseignement." Accessed March 20, 2021. https://www.quebec.ca/gouv/ministere/education/o rganismes-lies/comite-dagrement-des-programmesde-formation-a-lenseignement-capfe.

Ministère de l'éducation, Québec. 2021. "Québec Education Program.” Accessed March 12, 2021.

http://www.education.gouv.qc.ca/en/teachers/quebe c-education-program/. 
Ministère de l'éducation, Québec. 2021. "School Governance." Accessed March 18, 2021. https://www.quebec.ca/en/education/preschoolelementary-and-secondary-schools/schoolgovernance.

National Indigenous Economic Development Board. 2019. "The Indigenous Economic Progress Report 2019." Accessed April 16, 2021.

http://www.naedb-cndea.com/wpcontent/uploads/2019/06/NIEDB-2019-IndigenousEconomic- Progress-Report.pdf.

Natural Science and Engineering Research Council of Canada (NSERC). 2019. "Grant Recipients." Accessed April 28, 2021.

https://www.nserc-crsng.gc.ca/PromoterPromotion/PromoScience-PromoScience/RecipientsLaureats/index eng.asp.
Patterson, Martha, Myriam Hazel, and Dylan Saunders. 2019. "Annual Review of the Labour Market, 2018." Statistics Canada. Accessed March 20, 2021. https://www150.statcan.gc.ca/n1/pub/75-004m/75-004-m2019002-eng.htm.

Royal Commission on Aboriginal Peoples. 1996. "Volume 5: Renewal: A Twenty-Year Commitment." In Report of the Royal Commission on Aboriginal Peoples. Winnipeg: RCAP. Accessed April 7, 2021. http://data2.archives.ca/e/e448/e011188230-05.pdf.

Statistics Canada. 2016. "Data Products, 2016 Census." Accessed March 18, 2021. https://www12.statcan.gc.ca/censusrecensement/2016/dp-pd/index-eng.cfm.

Truth and Reconciliation Commission of Canada. 2015. "Truth and Reconciliation Commission of Canada: Calls to Action." Winnipeg: Truth and Reconciliation Commission of Canada. Accessed April 8, 2021. https://ehprnh2mwo3.exactdn.com/wpcontent/uploads/2021/01/Calls to Action English2.p df.

Emma C. Anderson is a 2nd year MSc student in Bioresource Engineering at McGill University. Her research applies a human-environmental system model to study interrelated water, food, and energy resource management problems. She advocates for solutions that consider both socioeconomic and environmental dimensions and how they interact. Emma hopes to pursue a career as an environmental policy analyst.

Kaitlyn Easson is a Ph.D. candidate in the Integrated Program in Neuroscience at McGill University. For her research, Kaitlyn uses quantitative magnitude resonance imaging techniques to study white matter structure in neonatal intensive care unit survivors. In addition to her research, Kaitlyn is also interested in science policy, outreach, and communication.

Saina Beitari, Ph.D., is a researcher at the National Research Council of Canada where she supports COVID19 and other viral infection R\&D efforts. She obtained her Ph.D. in Microbiology and Immunology from McGill University studying HIV/AIDS. Her passion for infectious diseases led her to work on a broad range of viruses of public health significance. Moving forward, Saina is aiming to advocate for better inclusion of science in public policymaking and to promote equity, diversity, and inclusion in the research community and beyond.

Maïa Dakessian is a 2nd year MSc student in Bioethics at the School of Public Health of the University of Montreal. She is interested in understanding the psychosocial impacts of existing language barriers that challenge access to healthcare services. Maïa is also the co-founder of the non-profit organization Science Policy in Health, Environment, Research and Ethics (SP.HERE) which works with communities to build an equitable and diverse society.

Sai Priya Anand is a Ph.D. candidate in the Microbiology and Immunology program, specializing in virology, at McGill University. Her research is focused on studying the body's humoral immune responses against HIV (causative agent of AIDS) and SARS-CoV-2 (causative agent of COVID-19). In addition to infectious diseases, Sai Priya is also interested in science communication as well as science and public health policy.

Sumedha Sachar, Ph.D., recently finished her Postdoctoral studies at CHU Ste Justine, Montreal where she worked on targeting Glioblastoma with liposome mediated miRNA, in mice. She is currently working as a Medical Writer where she works on informing patients and healthcare practitioners about the safety and 
efficacy of new oncology drugs coming into the market. She is also interested in science communication and outreach.

Jessica Bou Nassar is an MSc candidate in the Department of Bioresource Engineering at McGill University. Her research focuses on participatory modelling of human-water systems, using techniques that facilitate the inclusion of marginalized communities in model-building processes and decision-making. Her interests include community-based decision-making and science policy.

\section{Acknowledgements}

The authors would like to thank Anh-Khoi Trinh and Shawn McGuirk from Science \& Policy Exchange for comments and suggestions during the development of this policy memo. They would also like to thank their editor, Dilara Kiran, for feedback during the revisions.

Disclaimer

The authors declare no conflict of interest. 